\title{
Influence of Soil and Irrigation Water pH on the Availability of Phosphorus in Struvite Derived from Urine through a Greenhouse Pot Experiment
}

\author{
Xiaoning Liu, ${ }^{\dagger,}, \S$ Yi Tao, ${ }^{\dagger,}$ Guoqi Wen, ${ }^{\S}$ Fanxin Kong, ${ }^{\#}$ Xihui Zhang, ${ }^{\dagger, \ddagger}$ and Zhengyi $\mathrm{Hu}^{*, \S, \perp}$ \\ ${ }^{\dagger}$ Key Laboratory of Microorganism Application and Risk Control of Shenzhen and ${ }^{\ddagger}$ Tsinghua-Kangda Research Institute of \\ Environmental Nano-Engineering \& Technology, Graduate School at Shenzhen, Tsinghua University, Shenzhen 518055, China \\ ${ }^{\S}$ College of Resources and Environment, University of Chinese Academy of Sciences, Beijing 100049, China \\ ${ }^{\#}$ State Key Laboratory of Heavy Oil Processing, Beijing Key Laboratory of Oil \& Gas Pollution Control, China University of \\ Petroleum, Beijing 102249, China \\ ${ }^{\perp}$ Research Center for Eco-Environmental Sciences, Chinese Academy of Sciences, Beijing 100085, China
}

\begin{abstract}
One greenhouse pot experiment was used to investigate the availability of phosphorus in struvite derived from urine affected by soil $\mathrm{pH}$ (cinnamon soil, $\mathrm{pH} 7.3$; paddy soil, $\mathrm{pH} 5.3$ ) and irrigation water ( $\mathrm{pH} 6.0$ and 7.5) with bird rapeseed (Brassica campestris L.). The biomass of applied struvite in paddy soil was significantly greater than that of applied calcium superphosphate. However, statistically significant differences were not observed in cinnamon soil. Soil-applied struvite had a higher Olsen $\mathrm{P}$ compared to soil-applied calcium superphosphate irrespective of soil type. The biomass of applied struvite and irrigation with $\mathrm{pH} 6.0$ water was greater compared to that with irrigation with $\mathrm{pH} 7.3$ water irrespective of soil type, accompanied with significantly higher leaf chlorophyll concentration. Therefore, struvite has the potential to be an effective P fertilizer, and acidic irrigation water has greater influence on the availability of phosphorus in struvite than does acidic soil.
\end{abstract}

KEYWORDS: struvite, phosphorus, plant availability, soil, irrigation water

\section{INTRODUCTION}

Phosphorus (P), as an indispensable resource, is an essential nutrient for crop growth. The depletion timeline of $\mathrm{P}$ rock reserves ranges from 30 to 300 years. ${ }^{1}$ Although this estimation provides substantial uncertainty and more accurate data are lacking, there is no doubt regarding the irreversible depletion of high-concentration rock $\mathrm{P}$ reserves and the decline of the quality of the reserves (such as $\% \mathrm{P}$ and presence of impurities) over time, ${ }^{1}$ resulting in higher economic and energy cost for $\mathrm{P}$ exploitation. If $\mathrm{P}$ can be recovered in an economical way, it can re-enter the agricultural supply chain, displacing the consumption of traditional $\mathrm{P}$ fertilizer. It helps to create an ecofriendly environment by reducing the need for $\mathrm{P}$ rock $^{2}$ and to alleviate the $\mathrm{P}$ load emissions to water bodies. Human urine accounts for approximately $50 \%$ of the total P load in municipal wastewater, with $<1 \%$ of the total wastewater volume. ${ }^{3}$ Direct application of urine in agriculture is feasible in practice. ${ }^{4}$ However, huge quantities of separated urine are often difficult to transport and to store due to its unpleasant odor. Furthermore, health risk due to micropollutants and nitrogen (N) loss due to ammonia volatilization will be unavoidable during the application of urine to soil. Therefore, $\mathrm{P}$ recovery from urine in the form of struvite crystals will be a promising option with easy transportation, hygiene safety, and less nutrient loss.

Struvite crystal is formed with an equal molar concentrations of magnesium $(\mathrm{Mg})$, ammonium, and phosphate combined with six water molecules $\left(\mathrm{MgNH}_{4} \mathrm{PO}_{4} \cdot 6 \mathrm{H}_{2} \mathrm{O}\right)$, which contains $5.7 \% \mathrm{~N}, 12.6 \% \mathrm{P}$, and $9.9 \% \mathrm{Mg}$ by weight. The solubility of struvite is highly dependent on $\mathrm{pH},{ }^{5}$ and it is sparingly soluble in neutral and alkaline solutions, but readily soluble in acid solution. The $\mathrm{P}$ in the urine is mainly present as inorganic phosphate, and struvite obtained from urine has the advantages of higher $\mathrm{P}_{2} \mathrm{O}_{5}$ content (28.9\%) compared to common $\mathrm{P}$ fertilizer (e.g., $\mathrm{P}_{2} \mathrm{O}_{5}$ of calcium superphosphate, 12.0-16.0\%), slow release rate, and much lower impurity. ${ }^{6,7}$ Agronomic evaluation of struvite is important in determining the feasibility of $\mathrm{P}$ recovery from waste. It is known that water-soluble $\mathrm{P}$ fertilizer is generally considered to be fully plant available, and the $\mathrm{P}$ uptake from struvite has been studied in the greenhouse with a variety of test plants on soils compared with commercial $\mathrm{P}$ fertilizer. ${ }^{8-11}$ Antonini et al. ${ }^{12}$ evaluated the availability of urine-derived struvite as fertilizer and found that struvite led to biomass yield and $\mathrm{P}$ uptake comparable to or higher than those induced by a commercial mineral fertilizer. A few reports of the comparison of soils with different $\mathrm{pH}$ values can be found in previous research. ${ }^{10,13}$ Cabeza et al. ${ }^{10}$ studied the effectiveness of struvite as fertilizer compared with superphosphate and phosphate rock in a 2-year pot experiment with maize in two soils with contrasting $\mathrm{pH}$ (4.7 and 6.6) and concluded that struvite was as effective as superphosphate in both soils.

Although China's total reserves of $\mathrm{P}$ rock resources is rich, $>80 \%$ is low-grade phosphate rock, and $\mathrm{P}_{2} \mathrm{O}_{5}$ content is $<17 \%$ on average. ${ }^{14}$ The production of high-concentration $\mathrm{P}$ fertilizer is becoming more and more costly. Thus, it is urgent and

Received: January 5, 2016

Revised: $\quad$ March 21, 2016

Accepted: April 14, 2016

Published: April 14, 2016 
Table 1. Properties of Soils Used in Pot Trials $(n=4)^{a}$

$\begin{array}{cccccc}\text { soil } & \mathrm{pH} & \mathrm{SOM}(\mathrm{g} / \mathrm{kg}) & \mathrm{TN}(\mathrm{g} / \mathrm{kg}) & \mathrm{TP}(\mathrm{g} / \mathrm{kg}) & \text { Olsen P }(\mathrm{mg} / \mathrm{kg}) \\ \text { cinnamon } & 7.3 \pm 0.1 & 25.8 \pm 0.5 & 1.9 \pm 0.2 & 1.1 \pm 0.1 & 11.9 \pm 0.8 \\ \text { paddy } & 5.3 \pm 0.2 & 18.9 \pm 0.4 & 1.6 \pm 0.1 & 0.6 \pm 0.1 & 8.3 \pm 0.1\end{array}$

${ }^{a} \mathrm{SOM}$, soil organic matter; TN, total nitrogen; TP, total phosphorus; Oslen P, bicarbonate extractable P.

essential to study the potential and feasibility of recovering $\mathrm{P}$ from waste and to alleviate high consumption of $\mathrm{P}$ rock. However, limited information is known regarding the availability of struvite in soils with different $\mathrm{pH}$ values. There are various types of soils in China, and cinnamon soil and paddy soil are the most typical soil types in northern and southern China, respectively. Apart from soil properties, irrigation water will be an important factor influencing the release of nutrients from struvite and crop yield. Groundwater and rainwater are the primary resources as irrigation water. However, a rainwater harvesting system is being adopted for agricultural purposes to mitigate the decline of groundwater level and water shortages in China. Meanwhile, accompanying its rapid economic development and population growth, more and more areas in China have been suffering serious levels of acid rain. The mean $\mathrm{pH}$ value of acid rain was $<4.5$ in southern China, whereas the appearance of acid rain in northern China has been more and more frequent. ${ }^{15,16}$ Acid rain might affect the soil properties and microbial activities and more directly affect the solubility of struvite when applied to soil. However, few studies were found about the function of irrigation water on the application of struvite to soil.

The purpose of this research is to analyze the efficiency of struvite as $\mathrm{P}$ fertilizer in comparison to the synthetic fertilizer calcium superphosphate (CSP, a commercial P fertilizer) in two soils with different $\mathrm{pH}$ values. Furthermore, the influence of irrigation water with different $\mathrm{pH}$ values on effectiveness of struvite and biomass was also evaluated.

\section{MATERIALS AND METHODS}

Greenhouse Experiments. The pot experiments were carried out in a greenhouse of the Chinese Agricultural Academy, and bird rapeseed (Brassica campestris L.) was grown for 6 weeks in $1.0 \mathrm{~kg}$ of two soils (cinnamon soil and paddy soil). Details of the soils are shown in Table 1. The soils were ground in a porcelain mortar, passed through a $2 \mathrm{~mm}$ sieve for homogenization, mixed, and then placed into plastic pots without drainage holes. Four treatments were carried out: a control treatment, which received no P (control); one rate of CSP (CSP treatment); one rate of struvite (struvite treatment); and the last was one rate of struvite with irrigation water of $\mathrm{pH} 6.0$ (struvite and acid water treatment), obtained from the addition of $5 \%$ hydrochloric acid solution to tap water. The former were irrigated with tap water $(\mathrm{pH}$ 7.5). These treatments were all replicated four times in a randomized block design for each soil. Two P materials (CSP and struvite) were applied at a rate of $0.20 \mathrm{~g} \mathrm{P}_{2} \mathrm{O}_{5} / \mathrm{kg}$ soil based on the total $\mathrm{P}_{2} \mathrm{O}_{5}$ of the materials as received. To ensure other macroelements were not limiting, $0.2 \mathrm{~g} \mathrm{~N} / \mathrm{kg}$ soil and $0.1 \mathrm{~g} \mathrm{~K}_{2} \mathrm{O} / \mathrm{kg}$ soil were mixed with two soils for every pot with urea and potassium sulfate before the seeds were sown, respectively. Pots were brought to field capacity and regularly watered by weight, with no drainage from the pots. The pots were irrigated on a daily basis with tap water to maintain a level of $70 \%$ of soil water-holding capacity.

The CSP fertilizer was purchased commercially $\left(15 \% \mathrm{P}_{2} \mathrm{O}_{5}\right)$ and powdered. Struvite was obtained from hydrolyzed urine with the addition of magnesium chloride solution, ${ }^{17}$ dried, and lightly ground to match the particle size of the CSP. Compared to the pure struvite, the urine-derived struvite in this study contains $5.4 \% \mathrm{~N}, 11.8 \% \mathrm{P}(27.0 \%$ $\mathrm{P}_{2} \mathrm{O}_{5}$ ), and $9.5 \% \mathrm{Mg}$ as well as $0.7 \% \mathrm{Ca}, 0.1 \% \mathrm{~K}$, and $0.3 \% \mathrm{Na}^{17}$
Analytical Methods and Data Analysis. The bird rapeseed was harvested 6 weeks after sowing. Above-ground biomass was dried at 65 ${ }^{\circ} \mathrm{C}$ and then weighed. Soil samples were collected and analyzed for $\mathrm{pH}$, organic matter, total nitrogen, and Olsen $\mathrm{P}$. Soil $\mathrm{pH}$ was determined in water suspensions obtained at a soil/water ratio of 1:2.5 and then were measured using an HI98185A type $\mathrm{pH}$ meter (Hanna, Italy). Soil organic matter and total nitrogen were measured with potassium dichromate oxidation titration and the semimicro Kjeldahl method. ${ }^{18}$ Soil Olsen $\mathrm{P}$ and total $\mathrm{P}$ were obtained by using the $\mathrm{Mo}-\mathrm{Sb}$ colorimetric method. ${ }^{18}$ To measure the leaf $\mathrm{P}$ concentrations, the dry matter was ashed at $500{ }^{\circ} \mathrm{C}$ and dissolved in $25 \%$ hydrochloric acid solution. Leaf $\mathrm{P}$ concentrations were determined by using the $\mathrm{Mo}-\mathrm{Sb}$ colorimetric method, and leaf chlorophyll concentration was measured with an acetone extraction method. ${ }^{18}$ Cumulative shoot dry matter yield (above-ground biomass) were calculated by combing the data of the four harvests. All data were expressed as the observed mean, followed by its standard error $( \pm S E)$. The P use efficiency indicated the percentage of $\mathrm{P}$ uptake from the applied $\mathrm{P}$ fertilizer, which was obtained from the amount of $\mathrm{P}$ applied to the soil divided by the $\mathrm{P}$ uptake of above-ground leaf in this study. Statistical analysis (one-way ANOVA, followed by Scheffe post hoc test at $\alpha=0.05$ ) was performed by using SPSS Statistics 19.0.

\section{RESULTS AND DISCUSSION}

Above-ground Biomass Yield. Those plants that received CSP and struvite were visibly taller and stronger than the no-P controls. Above-ground biomass for all treatments is shown in Figure 1. All P resource treatments in cinnamon soil provided

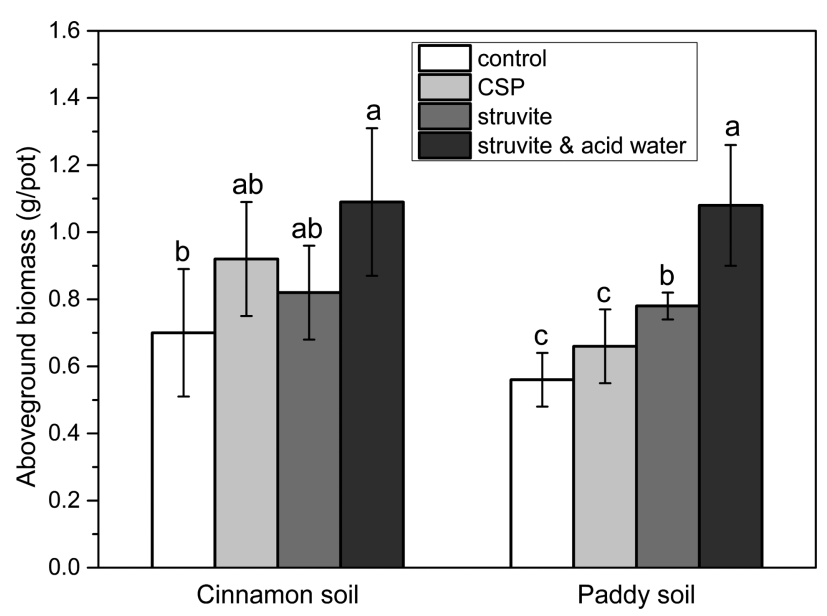

Figure 1. Above-ground biomass with different treatments. Values within the same column grouping designated with different letters indicate significant differences at $P<0.05(n=4)$.

significantly higher above-ground biomass than that of control. However, no significant difference of yield was found with CSP and struvite treatments compared to control. Struvite and acid water treatment also had significantly higher biomass than that of control, whereas no significant difference was found compared with the other two treatments (CSP and struvite treatments). In paddy soil, struvite and struvite and acid water treatments provided significantly higher above-ground biomass than those of control and CSP treatment, whereas CSP 
treatment had no significant difference in biomass compared to control. Meanwhile, the biomass in struvite and acid water treatment also showed significant difference from struvite treatment.

A similar conclusion was found by other researchers that struvite had comparative performance on crop biomass. Johnston and Richards ${ }^{8}$ found that dry matter yields of ryegrass and $\mathrm{P}$ offtakes given by the synthetic and recovered struvite were not significantly different statistically either between themselves or from monocalcium phosphate applied at the same rate. Ackerman et al. ${ }^{19}$ evaluated the manure-derived struvite as P source and demonstrated that biomass yields for manure-derived struvite and pure struvite were significantly smaller than those for monoammonium phosphate. The result is partly due to the lower solubility of the struvite applied in the alkaline soil ( $\mathrm{pH}$ 7.7). Thus, it is estimated in this study that application of struvite to paddy soil should have better performance on the yield than in cinnamon soil, because paddy soil has lower $\mathrm{pH}$ value, probably resulting in higher solubility of nutrient elements in struvite. Our results support this thought. Struvite had similar plant availability compared to CSP in cinnamon soil, whereas struvite had better performance than CSP in paddy soil. Several previous investigations have also suggested that struvite may be an effective fertilizer for acidic soil. ${ }^{8,20}$

Massey et al. ${ }^{10}$ conducted a greenhouse study with struvite and other $\mathrm{P}$ fertilizers at different soil $\mathrm{pH}$ levels and reported that struvite was effective at both acidic and slightly alkaline $\mathrm{pH}$ levels. However, it was found in our study that struvite in cinnamon soil ( $\mathrm{pH}$ 7.3) had lower performance on biomass compared to CSP treatment, but not significantly, but showed significantly higher level in biomass in paddy soil ( $\mathrm{pH}$ 5.3). The difference might be correlated with the crop and soil types. Meanwhile, lower soil $\mathrm{pH}$ value in acid soil might not be the only factor to affect the release of nutrients from struvite. Struvite treatment gave similar biomass compared to CSP treatment, but neither fertilizer significantly increased yield compared to the control, meaning that other factors also influenced crop growth. Le Corre et al. ${ }^{21}$ presented that plant availability of struvite might be influenced by a series of surrounding factors, such as temperature and ionic strength in the soil. Struvite dissolution might also be increased by an aerobic microbiological mineralization mechanism. ${ }^{22}$ Actually, although the same amount of $\mathrm{P}$ was applied to soil with struvite and CSP, the $\mathrm{N}$ and $\mathrm{Mg}$ in struvite and the calcium in CSP might also pose certain influences on the biomass of crops.

The biomasses in cinnamon and paddy soils both showed the highest values (1.09 and $1.08 \mathrm{~g} / \mathrm{kg}$ soil, respectively) with the struvite and acid water treatment. Struvite and acid water treatment exhibited the largest influence on yield for both of the two soils, which implies that the irrigation water also plays an important role in the plant availability of struvite as $\mathrm{P}$ resource. The solubility value of pure struvite increased significantly with increasing acidity of the water. ${ }^{21}$ Therefore, acid irrigation water contributed to the solubility of nutrients in struvite and improved the plant growth and yield because of quick solubility of $\mathrm{P}$ and additional $\mathrm{N}$ and $\mathrm{Mg}$ input apart from $\mathrm{P}$ resource. Furthermore, the quality of irrigation water might affect the solubility of struvite and the release period.

Leaf $P$ Concentration and $P$ Use Efficiency. Leaf $P$ concentrations with different treatments are presented in Figure 2. In cinnamon soil, the application of struvite as $\mathrm{P}$ resource had no significant influence on the leaf $\mathrm{P}$ concentration. In

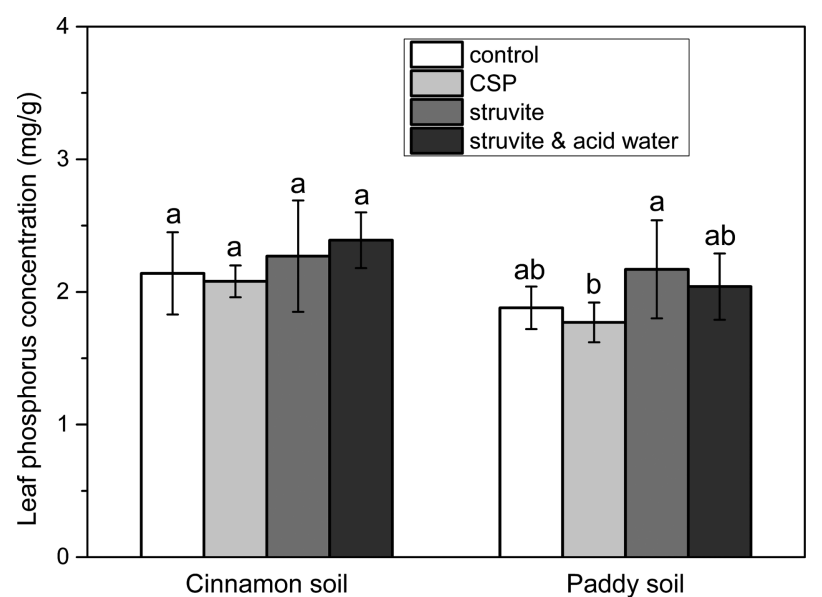

Figure 2. Leaf P concentration with different treatments. Values within the same column grouping designated by different letters indicate significant differences at $P<0.05(n=4)$.

paddy soil, a significant difference was observed only between CSP and struvite treatments. The average leaf P concentration ranged from 2.08 to $2.39 \mathrm{mg} / \mathrm{g}$ for cinnamon soil, whereas it ranged from 1.77 to $2.17 \mathrm{mg} / \mathrm{g}$ for paddy soil. In brief, the addition of $\mathrm{P}$ resource did not seem to have an obviously positive influence on the leaf $\mathrm{P}$ concentration, and the latter might be more correlated with climate, soil, and phylogeny. ${ }^{23}$ However, Massey et al. ${ }^{13}$ found that struvite treatment in soil $\mathrm{pH}$ of 6.5 increased the average plant $\mathrm{P}$ concentration more than the control, whereas in the limed soil of $\mathrm{pH} 7.6$ the plant $\mathrm{P}$ concentration was lower than the control. Their results might imply that acidic or slightly acidic soils also contribute to higher plant $\mathrm{P}$ concentration.

Table 2 presents the $\mathrm{P}$ use efficiency with $\mathrm{P}$ fertilizer treatments. The highest $\mathrm{P}$ use efficiency was found with struvite

Table 2. Leaf $P$ Use Efficiency (\%) with $P$ Fertilizer Treatments in the Pot Experiment

\begin{tabular}{lccc}
\multicolumn{1}{c}{ soil } & CSP & struvite & struvite and acid water \\
cinnamon & 2.26 & 1.95 & 2.98 \\
paddy & 1.42 & 1.58 & 2.52 \\
\hline
\end{tabular}

and acid water treatment in both soils. Higher P use efficiency was observed with CSP treatment than that of struvite treatment in cinnamon soil, whereas lower $\mathrm{P}$ use efficiency was found with CSP treatment in paddy soil. P use efficiency exhibited the highest values (2.98 and $2.52 \%)$ with struvite and acid water in cinnamon and paddy soils. It is obvious that irrigation with acid water would improve the $\mathrm{P}$ use efficiency in both soils. However, it is stated that the average recovery of $\mathrm{P}$ from fertilizer to crops during one growing season is only about $10 \%$ in China ${ }^{24,25}$ due to the binding capacity of the $\mathrm{P}$ with calcium ions in calcareous soil and the adsorption of $\mathrm{P}$ by iron and aluminum oxides in acidic soil. ${ }^{26}$ Meanwhile, the $\mathrm{P}$ use efficiency in this study was even lower compared to the usual $\mathrm{P}$ fertilizer application to soil. One reason was that the actual $\mathrm{P}$ use efficiency is strongly correlated with the crop species and application amount of fertilizer. Plaza et al..$^{9}$ demonstrated that the $\mathrm{P}$ uptake by ryegrass from the soil increased significantly with the increasing amount of $\mathrm{P}$ applied in the soil. The other reason was that the $\mathrm{P}$ uptake by rapeseed presented only the 
amount of $\mathrm{P}$ in the above-ground biomass, which did not contain the amount of $\mathrm{P}$ assimilated by the root.

Leaf Chlorophyll Concentration. Application of fertilizer (CSP or struvite) significantly enhanced the leaf chlorophyll concentration compared to control in both soils. Leaf chlorophyll concentration with struvite and acid water treatment showed the greatest values and increased from 1.0 to $1.5 \mathrm{mg} / \mathrm{g}$ and from 1.6 to $2.7 \mathrm{mg} / \mathrm{g}$ in cinnamon and paddy soils compared to control, respectively (Figure 3 ). Leaf

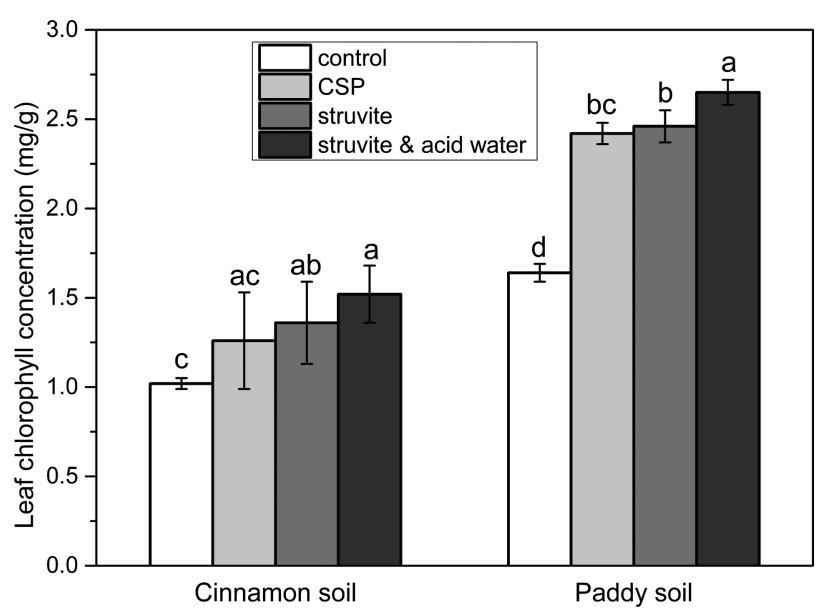

Figure 3. Leaf total chlorophyll concentration with different treatments in the pot experiment. Values within the same column grouping designated by different letters indicate significant differences at $P<0.05(n=4)$.

chlorophyll concentration is one of the indices of photosynthetic activity. On the basis of a test of fertilization variant, Bojovic and Stojanovic ${ }^{27}$ found that the lowest chlorophyll concentration in wheat was recorded on unfertilized soil, whereas the greatest leaf chlorophyll concentration was measured on the soil fertilized with $\mathrm{N}$ and $\mathrm{P}$. Thus, measuring leaf chlorophyll concentration can be determined to be an alternative method to gain understanding of crop photosynthesis and biomass. Many authors have also established that chlorophyll synthesis is dependent upon mineral nutrition. The $\mathrm{N}$ resource is a major constituent of several of the most important substances in plants, and application of $\mathrm{N}$ fertilizer would increase leaf chlorophyll. ${ }^{28}$ The P resource is involved in many metabolic processes essential for normal growth, such as photosynthesis, which exerts influence on the stability of the chlorophyll molecule. Vafaie et al. ${ }^{29}$ indicated that $\mathrm{Mg}$ also affected the leaf chlorophyll content of safflower because $\mathrm{Mg}$ resource is a component of chlorophyll and the activating agent of enzyme production. ${ }^{20}$ Thus, struvite and acid water treatment resulted in the highest leaf chlorophyll concentration due to the simultaneous release of $\mathrm{N}, \mathrm{P}$, and $\mathrm{Mg}$ from struvite.

Soil Olsen P. The soil Olsen $\mathrm{P}$ values in cinnamon and paddy soils decreased from 11.9 to $8.0 \mathrm{mg} / \mathrm{kg}$ and from 8.3 to $6.5 \mathrm{mg} / \mathrm{kg}$ with control, respectively, whereas they increased to $17.0,25.0$, and $21.7 \mathrm{mg} / \mathrm{kg}$ and 9.4, 12.8, and $11.8 \mathrm{mg} / \mathrm{kg}$ with CSP, struvite, and struvite and acid water treatment, respectively (Figure 4). Significant difference was found among all treatments, and the results indicated that adding $\mathrm{P}$ fertilizer could effectively increase the soil Olsen P in both soils. Compared to CSP treatment, struvite treatment led to obviously higher soil Olsen $\mathrm{P}$, and the highest soil Olsen $\mathrm{P}$ values were obtained with struvite treatment in both soils.

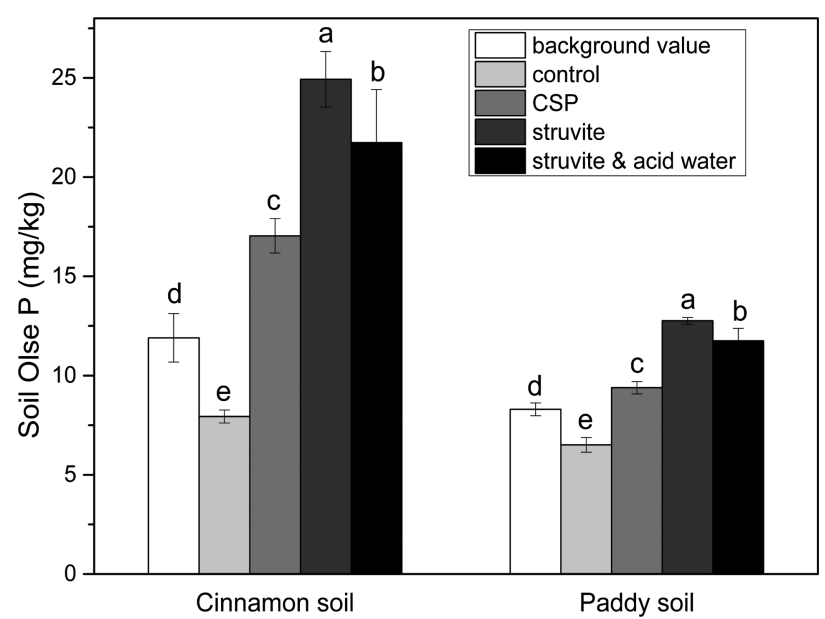

Figure 4. Soil Olsen $\mathrm{P}$ after harvesting with different treatments. Values within the same column grouping designated by different letters indicate significant differences at $P<0.05(n=4)$.

Higher Olsen $\mathrm{P}$ was found in cinnamon soil than in paddy soil. This result implies that $\mathrm{P}$ fertilizer is more beneficial in enhancing the soil Olsen $\mathrm{P}$ in cinnamon soil. Higher Olsen P with struvite treatment will have better influence on the next crop rotation.

The amount of soil Olsen $\mathrm{P}$ was selected as an alternative parameter to optimize soil $\mathrm{P}$ management, and the critical soil Olsen P level presents a level at which a further increase in soil $\mathrm{P}$ does not further increase yield. Bai et $\mathrm{al}^{30}$ thought that critical Olsen $\mathrm{P}$ values for crop yields in China ranged from 10 to $28 \mathrm{mg} / \mathrm{kg}$, depending on crop and soil types. Furthermore, soil structure, depth, and organic carbon will also be influencing factors. ${ }^{31}$ The soil Olsen P in both soils in this study was within the scope of the above findings. However, excessive Olsen $\mathrm{P}$ values above the critical $\mathrm{P}$ leaching level will greatly increase the risk of $\mathrm{P}$ loss to water bodies through runoff and erosion. ${ }^{32,33}$

It is known that soluble P fertilizer CSP can release $\mathrm{P}$ to the soil solution sufficiently quickly to meet the demand for $\mathrm{P}$ of most crops. Rahman et al. ${ }^{2}$ studied the $\mathrm{P}$ leaching rate in both struvite and fused superphosphate-urea-treated soil and found that $P$ leaching was very slow during the first 2 weeks and then rapidly increased during the following weeks. Latifian et al. ${ }^{34}$ studied the release of nutrients in recovered struvite from wastewater and found that the total $\mathrm{N}, \mathrm{P}$, and $\mathrm{Mg}$ released in the distilled water after 105 days were in the ranges of 9.623.2, 8.4-26.7, and 11.3-32.6\%, respectively. These findings suggested that the dissolution and release of $\mathrm{P}$ resource from struvite might be slower than that of commercial fertilizer (i.e., CSP). However, Johnston and Richards ${ }^{8}$ studied different precipitated phosphates as a $\mathrm{P}$ resource for plants besides the recovered struvite from the wastewater discharges. It was found that perennial ryegrass (Lolium perenne L.) took up about $90 \%$ of the P supplied in the form of struvite in two test soils. The difference might be attributed to the particle size of struvite used and soil properties. Although the release of P from struvite after application to soil was not clear in this study, higher soil Olsen P could be observed in both soils when struvite was added as P fertilizer compared to CSP. Compared to struvite treatment, lower soil Olsen $\mathrm{P}$ was found with struvite and acid water treatment due to the higher solubility of struvite and the larger P offtake by plants. 
Potential and Prospect of Struvite as Phosphorus Fertilizer. Plant $\mathrm{P}$ uptake from struvite exhibited similar or even better performance for the yield compared to CSP. A similar result was obtained by Römer, ${ }^{35}$ who also reported very good availability of struvite $\mathrm{P}$ for rye plants in a 3-week growth chamber trial. The author observed a high $\mathrm{P}$ uptake from struvite, which was not significantly different from that with $\mathrm{Ca}\left(\mathrm{H}_{2} \mathrm{PO}_{4}\right)_{2}$. In this study, the above-ground biomass in cinnamon soil had no significant difference from that of control and CSP treatments, whereas it was significantly higher than those in the paddy soil. The result suggested that soil $\mathrm{pH}$ was one of the most determining factors for the release of nutrients from struvite, and struvite might have higher plant availability in more acid soils. Several previous research studies have exhibited a similar conclusion. ${ }^{8,20}$ Compared to other fertilizers, the benefits of using struvite are low leaching rates and prolonged release of nutrients throughout the growing season of plants, ${ }^{36}$ which resulted in low leaching losses of nutrients in soil with irrigation and rain. It was also found that higher soil Olsen $\mathrm{P}$ could be seen with struvite treatment in both soils. Meanwhile, struvite is also a compound fertilizer, containing $\mathrm{Mg}$ and $\mathrm{N}$ resources simultaneously, which will also be beneficial to improve crop growth with the dissolution of struvite in the soil. This might be one reason struvite treatments provided significantly higher above-ground biomass than that of CSP treatment in paddy soil.

Traces of heavy metals are relatively low in the struvite used in this study, being below detection limits $(<0.001 \mathrm{mg} / \mathrm{L})$ for cadmium, copper, arsenic, and lead. ${ }^{17}$ A similar result can be found in the study of Ronteltap et al. ${ }^{37}$ However, struvite may still be coupled with other micropollutants in urine including pathogens and pharmaceuticals, and Decrey et al. ${ }^{38}$ found that infectivity and inactivation of viruses and eggs were influenced by the specific struvite drying condition. Although the application of struvite obtained from urine will be safe and feasible in theory, an essential evaluation will be required before the actual application of struvite to soil. By contrast, phosphate fertilizer application from raw $\mathrm{P}$ rock is a significant contributor of trace element, especially for $\mathrm{Cd}$ accumulation in cropland soils. $^{39}$

The dissolution and release of elements from struvite in acid soil or under acidly irrigation water should be studied to determine the quantity of struvite application in soil based on pot experiments with different kinds of crops. Fine struvite crystals obtained from a reactor will be in the form of powder when dried later, which is difficult to spread on land using control from equipment because it is too light. ${ }^{34}$ As supplied, this struvite could not find favor in agriculture. Struvite can be stored in a compact form, and it is easy and feasible to handle, transport, and apply, especially in granulated form. Starch and bentonite were found to be the most efficient in agglomerating struvite powder. ${ }^{34}$ Struvite coated with biochar-modified or biodegrable polymers ${ }^{4,41}$ will also be another solution to prolong the release property of struvite and to escape the too fast release of elements from struvite (particularly in rather acidic soil or with rather acidic irrigation water), which might improve the market potential of struvite as commercial fertilizer. Further growth chamber and field studies are needed to take these and other factors into account, including rotations, fertilizer placement, and hydrology.

The results demonstrate that struvite presented a comparative or even better influence on biomass of bird rapeseed in two soils with different $\mathrm{pH}$ values. Struvite had similar plant availability compared to CSP in cinnamon soil and better performance than that of CSP in paddy soil. Struvite might have higher plant availability influence on biomass yield of crop in more acid soils due to the higher solubility of struvite compared to CSP. Struvite as fertilizer can result in obviously higher soil Olsen P compared to CSP. Irrigation with slightly acid water posed a positive influence on yield and total chlorophyll content of leaf, which means that water quality of irrigation or rain will play a big role in applying struvite to soil. In brief, struvite has the potential to be an effective $P$ fertilizer and should be recommended for use in tropical and subtropical regions on the basis of the acidity of soil and irrigation water.

\section{AUTHOR INFORMATION}

\section{Corresponding Author}

*(Z.H.) E-mail: zhyhu@ucas.ac.cn. Phone: (86)-10-6254 0047. Fax: (86)-10-8825 6415.

\section{Funding}

This study was financially supported by the Key Projects of the National Science and Technology Pillar Programme of China (2012BAJ24B06-2B) and the China Postdoctoral Science Foundation (2015M581116).

\section{Notes}

The authors declare no competing financial interest.

\section{ACKNOWLEDGMENTS}

We express our appreciation to $\mathrm{Dr}$. $\mathrm{Fu} \mathrm{Li}$ from the Chinese Agricultural Academy for assistance during the pot experiment.

\section{ABBREVIATIONS USED}

$\mathrm{P}$, phosphorus; $\mathrm{Mg}$, magnesium; $\mathrm{N}$, nitrogen; $\mathrm{CSP}$, calcium superphosphate; Oslen $\mathrm{P}$, bicarbonate extractable $\mathrm{P}$

\section{REFERENCES}

(1) Cordell, D.; Drangert, J. O.; White, S. The story of phosphorus: global food security and food for thought. Global Environ. Change 2009, 19, 292-305.

(2) Rahman, M. M.; Liu, Y. H.; Kwag, J. H.; Ra, C. S. Recovery of struvite from animal wastewater and its nutrient leaching loss in soil. $J$. Hazard. Mater. 2011, 186, 2026-2030.

(3) Larsen, T. A.; Gujer, W. Separate management of anthropogenic nutrient solutions (human urine). Water Sci. Technol. 1996, 34, 87-94.

(4) Sene, M.; Hijikata, N.; Ushijima, K.; Funamizu, N. Effects of continuous application of extra human urine volume on plant and soil. Int. J. Agric. Sci. Res. 2013, 3, 75-90.

(5) Doyle, J. D.; Parsons, S. A. Struvite formation, control and recovery. Water Res. 2002, 36, 3925-3940.

(6) Parsons, S. A.; Smith, J. A. Phosphorus removal and recovery from municipal wastewater. Elements 2008, 4, 109-112.

(7) Winker, M.; Vinnerås, B.; Muskolus, A.; Arnold, U.; Clemens, J. Fertiliser products from new sanitation systems: their potential values and risks. Bioresour. Technol. 2009, 100, 4090-4096.

(8) Johnston, A. E.; Richards, I. R. Effectiveness of different precipitated phosphates as phosphorus sources for plants. Soil Use Manage. 2003, 19, 45-49.

(9) Plaza, C.; Sanz, R.; Clemente, C.; Fernandez, J. M.; Gonzalez, R.; Polo, A.; Colmenarejo, M. F. Greenhouse evaluation of struvite and sludges from municipal wastewater treatment works as phosphate sources for plants. J. Agric. Food Chem. 2007, 55, 8206-8212.

(10) Cabeza, R.; Steingrobe, B.; Romer, W.; Claassen, N. Effectiveness of recycled $\mathrm{P}$ products as $\mathrm{P}$ fertilizer, as evaluated in pot experiments. Nutr. Cycling Agroecosyst. 2011, 91, 173-184.

(11) Gell, K.; Ruijter, F. J.; Kuntke, P.; Graaff, M.; Smit, A. L. Safety and effectiveness of struvite from black water and urine as a phosphorus fertilizer. J. Agric. Sci. 2011, 3, 67-80. 
(12) Antonini, S.; Arias, M. A.; Eichert, T.; Clemens, J. Greenhouse evaluation and environmental impact assessment of different urinederived struvite fertilizers as phosphate source for plants. Chemosphere 2012, 89, 1202-1210.

(13) Massey, M. S.; Davis, J. G.; Ippolito, J. A.; Sheffield, R. E. Effectiveness of recovered magnesium phosphate as fertilizers in neutral and slightly alkaline soils. Agron. J. 2009, 101, 323-329.

(14) Lu, R. Phosphorus resource of China and phosphate fertilizer production and consumption I. $\mathrm{P}$ resources and $\mathrm{P}$ fertilizers production of China. Soils 2004, 36, 1-4.

(15) Zhao, Y.; Hou, Q. An analysis on spatial/ temporal evolution of acid rain in China (1993-2006) and its causes. Acta Meteorol. Sin. 2008, 66, 1032-1042 (in Chinese).

(16) Hou, Q.; Zhao, Y. An analysis on characteristics of regional acid rain over China in 2007. Adv. Clim. Change Res. 2009, 5, 7-11 (in Chinese).

(17) Liu, X.; Hu, Z.; Mu, J.; Zang, H.; Liu, L. Phosphorus recovery from urine with different magnesium resources in an air-agitated reactor. Environ. Technol. 2014, 35, 2781-2787.

(18) Lu, R. Soil Agrochemistry Analysis Method; China Agricultural Science and Technology Press: Beijing, 1999 (in Chinese).

(19) Ackerman, J. N.; Zvomuya, F.; Cicek, N.; Flaten, D. Evaluation of manure-derived struvite as a phosphorus source for canola. Can. J. Plant Sci. 2013, 93, 419-424.

(20) Li, X.; Zhao, Q. Recovery of ammonium-nitrogen from landfill leachate as a multi-nutrient fertilizer. Ecol. Eng. 2003, 20, 171-181.

(21) Le Corre, K. S.; Jones, E. V.; Hobbs, P.; Parsons, S. A. Phosphorus recovery from wastewater by struvite crystallization: a review. Crit. Rev. Environ. Sci. Technol. 2009, 39, 433-477.

(22) Rothbaum, H. P.; Rohde, A. G. Long-term leaching of nutrients from magnesium ammonium phosphate at various temperatures. N.Z. J. Exp. Agric. 1976, 4, 405-413.

(23) Yang, X.; Chi, X.; Ji, C.; Liu, H.; Ma, W.; Mohhammat, A.; Shi, Z.; Wang, X.; Yu, S.; Yue, M.; Tang, Z. Variations of leaf N, P concentrations in shrubland biomes across northern China: phylogeny, climate and soil. Biogeosci. Discuss. 2015, 12, 18973-18998.

(24) Wang, J. Q. Analysis and Evaluation of Yield Increase of Fertilization and Nutrient Utilization Efficiency for Major Cereal Crops in China. Ph.D. thesis, China Agricultural University, Beijing, 2007 (in Chinese).

(25) Shen, J.; Li, R.; Zhang, F.; Fan, J.; Tang, C.; Rengel, Z. Crop yields, soil fertility and phosphorus fractions in response to long-term fertilization under the rice monoculture system on a calcareous soil. Field Crop. Res. 2004, 86, 225-238.

(26) Hinsinger, P. Bioavailability of soil inorganic $P$ in the rhizosphere as affected by root-induced chemical changes: a review. Plant Soil 2001, 237, 173-195.

(27) Bojović, B.; Stojanović, J. Chlorophyll and carotenoid content in wheat cultivars as a function of mineral nutrition. Arch. Biol. Sci. 2005, 57, 283-290.

(28) Aroiee, H.; Omidbaigi, R. Effects of nitrogen fertilizer on productivity of medicinal pumpkin. Acta Hortic. 2004, 629, 415-419.

(29) Vafaie, A.; Ebadi, A.; Rastgou, B.; Moghadam, S. H. The effects of potassium and magnesium on yield and some physiological traits of safflower (Carthamus tinctorius). Int. J. Agric. Crop Sci. 2013, 5, 18951900.

(30) Bai, Z.; Li, H.; Yang, X.; Zhou, B.; Shi, X.; Wang, B.; Li, D.; Shen, J.; Chen, Q.; Qin, W.; Oenema, O.; Zhang, F. The critical soil P levels for crop yield, soil fertility and environmental safety in different soil types. Plant Soil 2013, 372, 27-37.

(31) Poulton, P. R.; Johnston, A. E.; White, R. P. Plant-available soil phosphorus: part I: the response of winter wheat and spring barley to Olsen P on a silty clay loam. Soil Use Manage. 2013, 29, 4-11.

(32) Sharpley, A. N.; Foy, B.; Withers, P. Practical and innovative measures for the control of agricultural phosphorus losses to water: an overview. J. Environ. Qual. 2000, 29, 1-9.

(33) Sharpley, A. N.; Kleinman, P. J. A.; Jordan, P.; Bergström, L.; Allen, A. L. Evaluating the success of phosphorus management from field to watershed. J. Environ. Qual. 2009, 38, 1981-1988.
(34) Latifian, M.; Liu, J.; Mattiasson, B. Struvite-based fertilizer and its physical and chemical properties. Environ. Technol. 2012, 33, 26912697.

(35) Römer, W. Plant availability of P from recycling products and phosphate fertilizers in a growth-chamber trial with rye seedlings. $J$. Plant Nutr. Soil Sci. 2006, 169, 826-832.

(36) Gaterell, M. R.; Gay, R.; Gochin, R. J.; Laster, J. N. An economic and environmental evaluation of the opportunities for substituting phosphorus recovered from wastewater treatment works in existing UK fertilizer markets. Environ. Technol. 2000, 21, 1067-1084.

(37) Ronteltap, M.; Maurer, M.; Gujer, W. The behaviour of pharmaceuticals and heavy metals during struvite precipitation in urine. Water Res. 2007, 41, 1859-1868.

(38) Decrey, L.; Udert, K. M.; Tilley, E.; Pecson, B. M.; Kohn, T. Fate of the pathogen indicators phage ФX174 and Ascaris suum eggs during the production of struvite fertilizer from source-separated urine. Water Res. 2011, 45, 4960-4972.

(39) McLaughlin, M. J.; Tiller, K. G.; Naidu, R.; Stevens, D. P. Review: the behaviour and environmental impact of contaminants in fertilizers. Aust. J. Soil Res. 1996, 34, 1-54.

(40) González, M. E.; Cea, M.; Medina, J.; Navia, R. Evaluation of biodegradable polymers as encapsulating agents for the development of a urea controlled-release fertilizer using biochar as support material. Sci. Total Environ. 2015, 505, 446-453.

(41) Zhou, Z.; Du, C.; Li, T.; Shen, Y. Biodegradation of a biocharmodified waterborne polyacrylate membrane coating for controlledrelease fertilizer and its effects on soil bacterial community profiles. Environ. Sci. Pollut. Res. 2015, 22, 8672-8682. 